\title{
A Hierarchical Learning Model Based on Deep Learning and Its Application in a SPOC and Flipped Classroom
}

\author{
https://doi.org/10.3991/ijet.v16i09.23009 \\ Xiangming An ${ }^{(凶)}$, Chengliang Qu \\ Jilin Institute of Chemical Technology, Jilin, China \\ an8102@163.com
}

\begin{abstract}
In accordance with the progressive knowledge-to-ability transformation laws, a hierarchical learning model composed of cognitive layer, application layer, and design layer was created and applied to college computer teaching. This model was used to facilitate the deep learning among students through the association establishment, step-by-step understanding, and comprehensive application of new and old knowledge. In the teaching design process, the "5-problem" teaching, which centered on "student-problemactivity-resource," was conducted and applied to the "Small Private Online Course (SPOC) + flipped classroom." The teaching result was assessed using the proposed hierarchical classification method. Results demonstrate that the improved teaching model remarkably enhances the ability of noncomputer major students to solve the practical problems encountered in their specialties by virtue of computational thinking through the data analysis of evaluation results and students' survey feedback. The students obviously speak more highly of the improved teaching model than the traditional blended teaching in the aspects of teaching content organization, learning effect, integration degree with the specialty and satisfaction. The degree of their participation in the flipped classroom reached as high as $90 \%$.
\end{abstract}

Keywords - Deep learning, hierarchical learning model, computational thinking, blended teaching

\section{Introduction}

The COVID-19 outbreak at the beginning of 2020 greatly affected the normal teaching of schools at all levels across the globe. Schools were closed to different degrees and replaced by large-scale online teaching in succession to cope with this epidemic crisis [1-3]. The traditional classroom and online classroom present longterm coexistence and deep integration after the epidemic is alleviated [4]. With the extensive implementation of blended classroom teaching, many institutions of higher learning have adopted the blended teaching model in basic computer course with comprehensive consideration of the course features, limitation of credit hours, knowledge freshness, and sharing of faculties from famous schools. 
Basic computer course is a core general course for noncomputer majors in institutions of higher learning. College students with noncomputer majors can master the basic concepts, basic principles, and basic methods of computer science by learning this course. They can cultivate their ability to solve practical problems in their own specialties through computational thinking. This course basically decides the future basic information literary of modern college students. Thus, enhancing the teaching effect of this course is of great importance to students' abilities in solving practical problems via information technology. Although students have preliminarily acquired the basic abilities to use computer to obtain, process, and transmit information through blended learning, they lack the abilities to solve comprehensive problems with the help of computer and the autonomous learning and collaborative learning abilities by modern IT means. Thus, the students always rest on surface learning, namely, low-order thinking, due to the shortage of proactive exploration, migration, and application of knowledge and innovative thinking. Therefore, they fail to solve practical problems on new application scenarios. Hence, improving the teaching quality of college computer courses and facilitating their students to master information processing techniques through teacher imparting, collaborative learning, and self-learning are currently important research problems among educators. These processes enable to reach the goal of solving the application problems related to their own majors by virtue of computational thinking.

The teaching practice of college computer course is taken as an example. A hierarchical learning model is proposed in this study to facilitate deep learning and then applied to "SPOC + flipped classroom" blended teaching for reaching the teaching objectives.

\section{State of the Art}

College computer courses are characterized by "diversification, modularization, integration, and networking" [5]. Much research work has been conducted regarding teaching reform to improve the computer teaching quality in universities and colleges and strengthen students' abilities to solve comprehensive problems through computational thinking.

Zhang combined Rain Classroom and Educoder platform to construct a blended teaching model for the fundamentals of college computer [6]. Being highly efficient, this blended teaching model facilitated the multichannel teacher-student interaction and problem feedback in the teaching cycle. However, how to solve the problems faced in teaching, guiding students' thinking by using these interactions and feedback, and improving the teaching quality was not described in detail. Wang built an intelligent teaching model for basic computer courses in colleges [7]. The model design was detailed in the pre-class, in-class, and after-class processes from the aspect of course deployment, followed by the data acquisition, analysis, and prediction of behavior in the whole learning process. However, only the design approach was given. This approach can be easily stuck in various problems, such as extremely ambiguous learning behavior of data feedback and multi-evaluation and lack of 
flexible teaching methods when applied in practical teaching. The improvement degree of teaching quality achieved by this teaching method remains to be further investigated. Fang introduced the implementation strategies and processes of "MOOC+ SPOC+ flipped classroom" blended teaching model and realized the blended classroom teaching [8]. However, problems, such as incomplete multilayer teaching task decomposition, neglection of student analysis, and insufficient degree of students' participation in learning are encountered. Uzun deemed that the way that students learn does not change although the blended learning changed the learning environment [9]. Hence, guiding the students to expand their knowledge breadth, deeply mining the relevant information, inspiring their innovative thinking, exercising their autonomous learning ability, and improving the teaching quality are difficult if the student situation, teaching method, knowledge point characteristics, and teaching feedback are rarely explored in the course reform.

Asicainen pointed out that successful learning and studying in higher education should involve students in deep learning [10]. In 1976, the concept of deep learning was introduced by Marton [11], who divided learning into surface-level and deeplevel by exploring the qualitative differences in outcome due to different learning processes of students. Subsequently, Biggs and Entwistle et al. further expounded the characteristics of the two learning levels [12-15]. For the surface approach, learners aim to replicate or understand knowledge contents superficially, and the learning process is characterized by rote memorization or mechanical memory. For the deep approach, learners are intended to acquire a full understanding of knowledge contents, associate them with priori knowledge, seek for the underlying principles, weigh the relevant evidence, and crucially evaluate the knowledge. Feng believed that the two different learning processes result in the difference of learning quality [16]. To sum up, the learning quality of students is significantly improved if guided to deep learning.

How to conduct deep learning has been explored by some scholars. Trigwell et al. thought that the students can be inspired by the interests in learning contents and the intension of active learning and thinking to conduct deep learning by using Approaches to Teaching Inventory [17]. Slack proposed that students' deep learning can be promoted by solving problems in a simulated real environment in academic atmosphere [18]. He analyzed the influence degrees of synchronous communication and online meetings on deep learning through the SOLO taxonomy. Diana obtained that the problem-based learning method can enhance deep learning by analyzing the experimental data [19]. However, effective measurement methods are lacking in her study. Dinsmore et al. indicated that further defining deep learning, establishing a clear theoretical framework, and using tools to measure the deep learning effect are necessary [20]. However, effective evaluation criteria are lacking. Through the above literature analysis, the key to improve the teaching quality depends on formulating proper teaching methods to facilitate the deep learning and verify effectively.

A hierarchical learning model is established in the blended classroom teaching process to enhance the progressive understanding of knowledge from low to high difficulty levels and the associated application and effectively promote students' deep learning. This model is used to conduct better college computer course reform. The 
"5-problem method" runs through the whole teaching process, and the quantitative evaluation is conducted by using the hierarchical classification method to ensure reaching the teaching objectives.

\section{$3 \quad$ Teaching Design}

On the basis of computational thinking theory of Wing [21], knowledge decomposition was implemented from the computer teaching process in accordance with the progressive knowledge-to-ability transformation. A hierarchical learning model was designed. Each knowledge module deepens the deep learning through the associated construction of cognitive layer, application layer, and design layer, as shown in Figure 1. The course design and teaching method based on the hierarchical learning model are introduced.

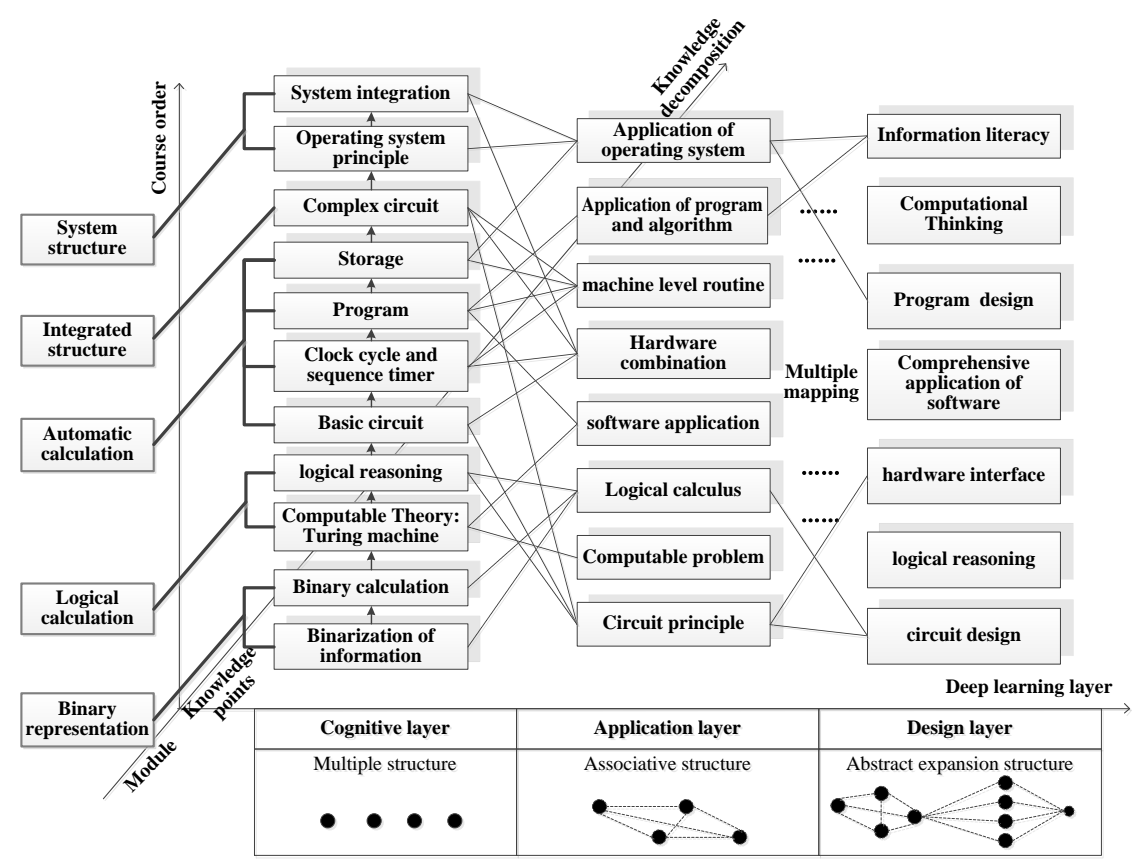

Fig. 1. Hierarchical Learning Model

\subsection{Course design}

The course design includes the early-stage analysis, design of course standard, overall plan, teaching program, and teaching content.

First, early-stage analysis includes the investigation on students' characteristics, survey of learning foundation, formulation of course objectives, analysis of blended 
learning environment, and positioning of occupational post demands. The feasibility report of blended teaching under the perspective of deep learning is obtained.

Second, formulation of course standard includes the compilation of course standard, study of teaching program, and formation of overall course program and report.

Third, appropriate teaching content is formulated. The organization of teaching content, determination of teaching objectives, and allocation of credit hours are realized in accordance with the proposed hierarchical learning model to achieve the goals of deep learning.

Table 1. Teaching Contents and Teaching Objectives at Different Cognitive Layers

\begin{tabular}{|l|l|l|l|c|c|}
\hline $\begin{array}{c}\text { Cognitive } \\
\text { layer }\end{array}$ & \multicolumn{1}{|c|}{ Feature } & $\begin{array}{l}\text { Teaching content } \\
\text { program }\end{array}$ & $\begin{array}{l}\text { Teaching } \\
\text { objective }\end{array}$ & $\begin{array}{c}\text { Theoretical } \\
\text { credit hours }\end{array}$ & $\begin{array}{c}\text { Experimental } \\
\text { credit hours }\end{array}$ \\
\hline $\begin{array}{l}\text { Cognitive } \\
\text { layer }\end{array}$ & $\begin{array}{l}\text { Understand the } \\
\text { fundamentals of } \\
\text { information technology } \\
\text { and meaning of } \\
\text { computational thinking }\end{array}$ & $\begin{array}{l}\text { Computational } \\
\text { method and } \\
\text { thinking }\end{array}$ & $\begin{array}{l}\text { Knowledge } \\
\text { and interest }\end{array}$ & 8 & 0 \\
\hline $\begin{array}{l}\text { Application } \\
\text { layer }\end{array}$ & $\begin{array}{l}\text { Solve computable } \\
\text { problems through } \\
\text { computational thinking }\end{array}$ & $\begin{array}{l}\text { Data and data } \\
\text { processing }\end{array}$ & $\begin{array}{l}\text { Application } \\
\text { and ability }\end{array}$ & 12 & 12 \\
\hline Design layer & $\begin{array}{l}\text { Design new computational } \\
\text { methods to solve } \\
\text { computable problems }\end{array}$ & $\begin{array}{l}\text { Combination of } \\
\text { computational } \\
\text { thinking and } \\
\text { professional } \\
\text { problems }\end{array}$ & $\begin{array}{l}\text { Thinking and } \\
\text { innovation }\end{array}$ & 20 & 20 \\
\hline
\end{tabular}

From the organization of course contents at each layer, the course teaching contents are constructed, selected, and determined, and then the minimum set of course teaching contents suitable for computer general education is formed. Other teaching content modules with respect to this are extended, and the students can be enabled to conduct autonomous learning and collaborative learning after class by utilizing IT and rich network teaching resources. Different teaching methods are designed specific to different teaching activities and then assessed using different evaluation methods on the basis of the differences between the cognitive layer, application layer, and design layer in the teaching objectives.

\subsection{Formulation of evaluation scheme}

The evaluation mechanism is formulated through the hierarchical classification method. In accordance with the characteristics of multilayer (cognitive layer, application layer, and design layer) learning contents, the related evaluation methods, such as platform testing, group cooperation, peer review, intergroup evaluation, interview defense, practical operation, assignment display, and online examination are flexibly chosen. The "self-evaluation-student evaluation-teacher evaluationcomputer evaluation" is perfected, as shown in Figure 2. 


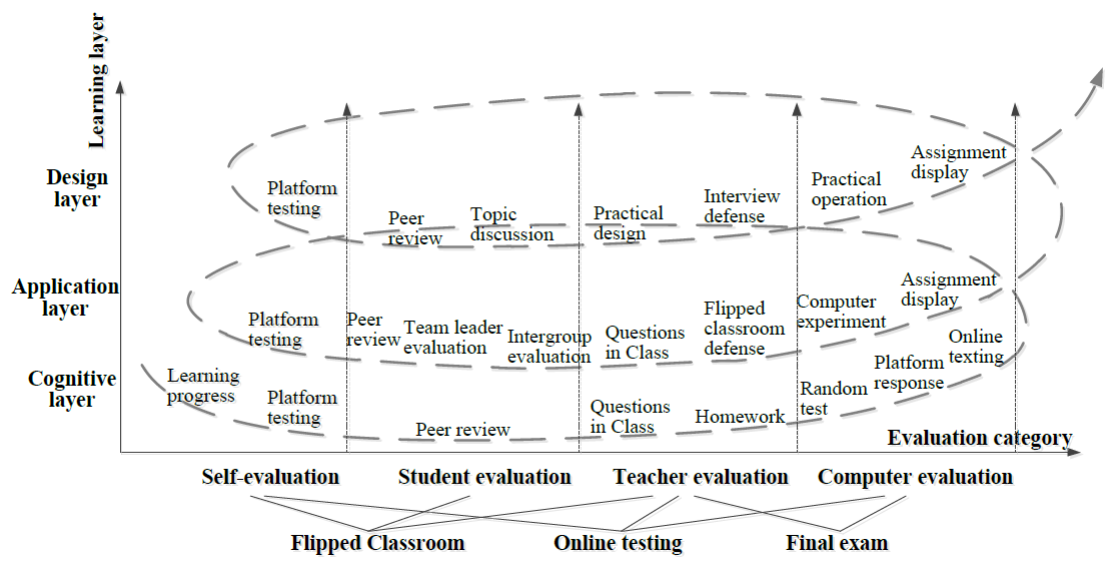

Fig. 2. Hierarchical Classification-based Evaluation Mechanism

The importance degrees of evaluation indexes are quantitatively sorted using the Technique for Order of Preference by Similarity to Ideal Solution (TOPSIS) method. Detailed evaluation criteria and scoring rules are formulated, and a scientific evaluation scheme is obtained.

The basic idea of TOPSIS method is to find the best and worst schemes (expressed by the optimal vector and worst vector, respectively) on the basis of the normalized original data matrix. The distances from each evaluation object to the ideal solution and the negative ideal solution are calculated, and the relative approaching degree of each evaluation object to the ideal solution is acquired, which is taken as the basis for evaluating the scheme quality.

1. Construct an initial evaluation matrix: The decision matrix has $m$ expert scores $f_{j}(j=1,2, \cdots, m)$ and $n$ evaluation indexes $Z_{i}=\left(Z_{i 1}, Z_{i 2}, \ldots, Z_{i m}\right)(i=1,2, \ldots, n)$. $X_{i j}$ is the score given by expert $j$ to index $i$, and the initial evaluation matrix $X$ is listed as follows:

$$
X=\left[\begin{array}{cccc}
X_{11} & X_{12} & \ldots & X_{1 m} \\
X_{21} & X_{22} & \ldots & X_{2 m} \\
& & & \\
\ldots & \ldots & \ldots & \ldots \\
X_{n 1} & X_{n 2} & \ldots & X_{n m}
\end{array}\right]
$$

2. Normalize the evaluation matrix: In the evaluation model, the key evaluation indexes include the percentage of learning schedule completed, platform testing, peer review, classroom questioning, defense in flipped classroom, random problem extraction, and preemptive reply on platform. If the evaluation criteria vary from expert to expert, normalizing the indexes is necessary. Specifically, the absolute evaluation values need to be transformed into relative values, so as to solve the homogeneity problem of different index values. Here, the values are transformed through Formula (2), and the data converted are then properly adjusted. 


$$
X_{i j}^{\prime}=\left\{\begin{array}{c}
x_{i j} \text { high }- \text { priority indexes } \\
1 / x_{i j} \text { low }- \text { priority indexes } . \\
M /\left(M+\left|x_{i j}-M\right|\right) \text { neutral indexes }
\end{array}\right.
$$

All low-priority indexes and neutral indexes are converted into high-priority index $X_{i j}^{\prime}$. For convenience, $X_{i j}^{\prime}$ is still denoted as $X_{i j}$ in the transformed matrix, followed by the normalization processing.

$$
z_{i j}=\frac{x_{i j}}{\sqrt{\sum_{i=1}^{n}\left(x_{i j}\right)^{2}}}
$$

The normalized matrix $Z$ is obtained on this basis as below.

$$
Z=\left[\begin{array}{ccccc}
z_{11} & z_{12} & \ldots & z_{1 m} \\
z_{21} & z_{22} & \ldots & z_{2 m} \\
& \ldots & \ldots & \\
z_{n 1} & z_{n 2} & \ldots & z_{n m}
\end{array}\right]
$$

Calculate the weighted decision matrix: The standardized evaluation matrix $Z$ that underwent dimensionless processing is multiplied by the weight matrix $W$ of the authority degree of each expert to obtain the weighted decision matrix $U$, where

$$
\begin{gathered}
u_{i j}=\sum_{j=1}^{m} z_{i j} * w_{j k}, i=1,2, \ldots, n ; k=1,2, \ldots, m . \\
U=\left[\begin{array}{ccccc}
z_{11} & z_{12} & \ldots & z_{1 m} \\
z_{21} & z_{22} & \ldots & z_{2 m} \\
\ldots & \ldots & \ldots & \ldots \\
z_{n 1} & z_{n 2} & \ldots & z_{n m}
\end{array}\right]\left[\begin{array}{cccc}
w_{11} & 0 & \ldots & 0 \\
0 & w_{22} & \ldots & 0 \\
\ldots & \ldots & \ldots & \ldots \\
0 & 0 & \ldots & w_{m m}
\end{array}\right]=\left[\begin{array}{cccc}
u_{11} & u_{12} & \ldots & u_{1 m} \\
u_{21} & u_{22} & \ldots & u_{2 m} \\
\ldots & \ldots & \ldots & \ldots \\
u_{n 1} & u_{n 2} & \ldots & u_{n m}
\end{array}\right](5)
\end{gathered}
$$

3. Determine the positive and negative ideal solutions: The positive ideal solution $U^{+}$is composed of maximum value in each column of $U$.

$U^{+}=\left(U_{1}^{+}, U_{2}^{+}, \ldots, U_{m}^{+}\right), U_{j}^{+}=\left\{\max u_{i j} \mid i=1,2, \ldots, n\right\}, j=1,2, \ldots, m$

Similarly, the negative ideal solution $U-$ consists of minimum value in each column of $U$.

$$
U^{-}=\left(U_{1}^{-}, U_{2}^{-}, \ldots, U_{m}^{-}\right), U_{j}^{-}=\left\{\min u_{i j} \mid i=1,2, \ldots, n\right\}, j=1,2, \ldots, m
$$

4. Calculate the Euclidean distances: Calculate the weighted Euclidean distances of each alternative from the ideal solution and the negative ideal solution.

$$
\begin{aligned}
& D_{i}^{+}=\sqrt{\sum_{j=1}^{m}\left(\max u_{i j}-u_{i j}\right)^{2}} \\
& D_{i}^{-}=\sqrt{\sum_{j=1}^{m}\left(\min u_{i j}-u_{i j}\right)^{2}}
\end{aligned}
$$


5. For each alternative, calculate the ratio $\boldsymbol{C}_{\boldsymbol{i}}$ as

$$
C_{i}=\frac{D_{i}^{-}}{D_{i}^{+}+D_{i}^{-}} 0 \leq C_{i} \leq 1
$$

The closer the $C_{i}$ to 1 , the more important the evaluation index. Therefore, $C_{i}=1$ if $U_{i}$ is an ideal solution, and $C_{i}=0$ if it is a negative ideal solution. The closer the $U_{i}$ to the ideal solution, the more approximate the $C_{i}$ to $1 . C_{i}$ can be ranked to give the scientific evaluation criteria on the weight setting basis of learning evaluation indexes.

\subsection{Hierarchical blended teaching method}

The corresponding blended teaching method is designed in accordance with the characteristics of teaching contents at each layer. This process is performed to improve the teaching quality of course contents at different layers and satisfy the learning needs of students with different learning bases.

Connotative blended teaching: Connotative blended teaching refers to revealing the computer essence by explaining the computing theory, computer system, and computer language at the cognitive layer, as shown in Figure 3. During the teaching process, the related knowledge is extended by giving full play to the high-quality online teaching resources of school SPOC to compensate the students' individual differences and cultivate their cognition and interests.

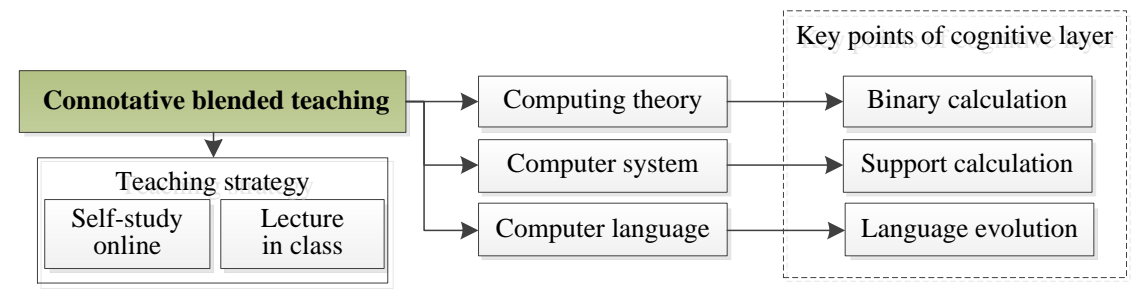

Fig. 3. Connotative Blended Teaching

Case-based blended teaching: Case-based blended teaching is mainly applied to the case interpretation of concepts and operations related to logical calculus, computer application, algorithm, and programming (Figure 4). The students' habits of deep thinking and extensive association are cultivated through simulation and verification, thereby further improving their knowledge application abilities.

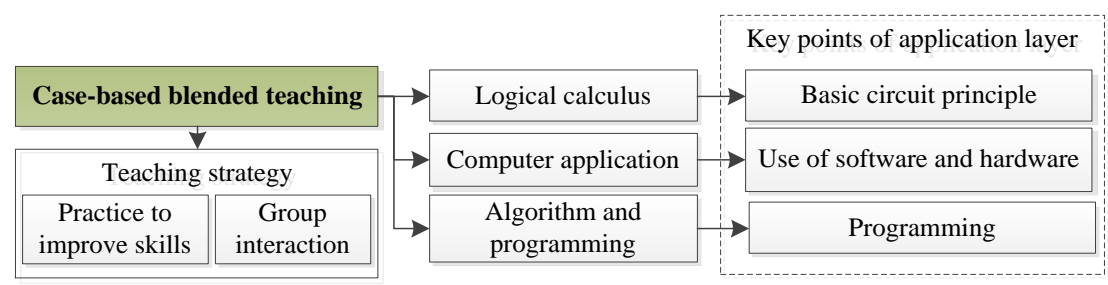

Fig. 4. Case-based Blended Teaching 
Evolution-based blended teaching: Mainly applied to the design layer, evolutionbased blended teaching refers to introducing the software and hardware integrated application and programming through the case demonstration in classroom. This explorative learning style can strengthen the students' abilities to solve professional problems through comprehensive knowledge and program thinking and enlighten their ways of thinking and consciousness of innovation deeply, as shown in Figure 5.

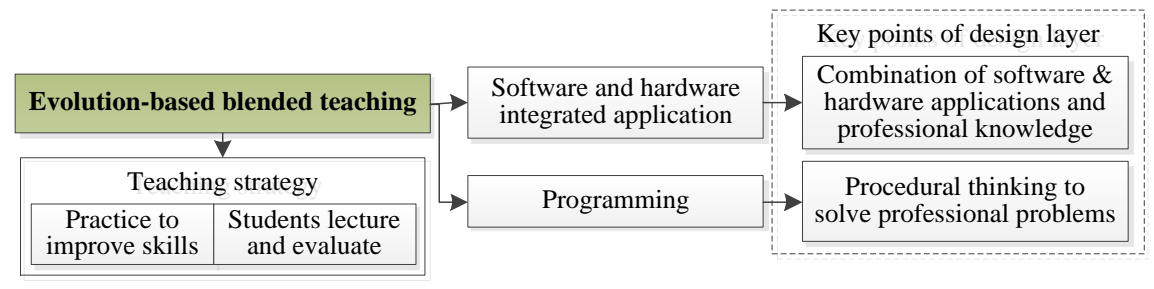

Fig. 5. Evolution-based Blended Teaching

\section{$4 \quad$ Teaching Implementation and Teaching Effect}

The learning objectives, key teaching points, teaching implementation plan, assessment, and evaluation criteria, were formulated for each knowledge point. The learning resources and toolkits required were issued, and the classroom teaching was conducted using the "5-problem method" (pose the problem, analyse the problem, solve the problem, extend the problem, and evaluate the problem) by centring on "student-problem-activity-resource," as shown in Figure 6.

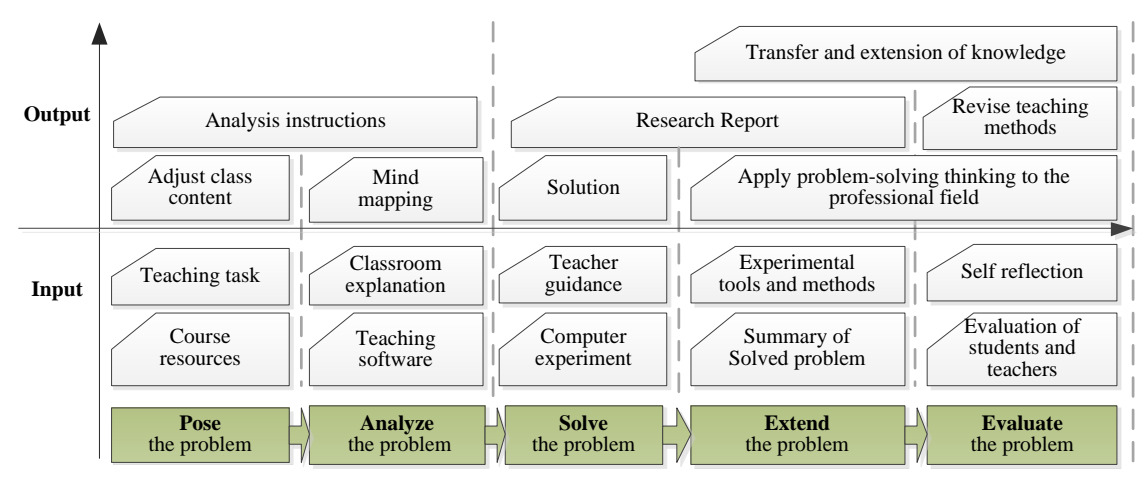

Fig. 6. "5-problem" Teaching

\subsection{Teaching implementation}

The execution of machine-level routine is a core module of college computer course. Here, the execution process of machine-level routine is taken for example to introduce the concrete teaching process through the hierarchical learning model. 
Pose the problem: The teacher raised the problem via the online learning platform before the class. How can the automatic solving of polynomial $(6 * 4+5) * 3$ through the computer system be realized? The students thought about the problem-solving methods by searching information, such as machine language and John von Neumann theory. Online real-time discussion proceeded between the teacher and students. The conclusion was obtained through the online layer-by-layer progressive guidance given by the teacher as follows: The algorithm and program of machine-level routine should be compiled using the basic hardware in the computer system in accordance with understandable and executable rules, and the calculation is performed in the end.

The students summarized the machine instructions required in this case through self-learning, as shown in Table 2.

Table 2. Machine Instructions

\begin{tabular}{|l|l|c|l|}
\hline \multicolumn{3}{|c|}{ Machine instruction } & \multicolumn{1}{c}{ Function } \\
\hline Fetch & \multicolumn{1}{|c|}{ Op-code } & Address code & \\
\hline Save & 000001 & $\mathrm{X}$ & $\begin{array}{l}\text { Fetch the number in memory cell X out and send to } \\
\text { the arithmetic unit }\end{array}$ \\
\hline Addition & 000010 & $\mathrm{Y}$ & $\begin{array}{l}\text { Save the number in arithmetic unit into memory cell } \\
\text { Y }\end{array}$ \\
\hline Multiplication & 000100 & $\mathrm{Z}$ & $\begin{array}{l}\text { Add the number in arithmetic unit to the number in } \\
\text { memory cell Z, and reserve the result in the arithmetic } \\
\text { unit }\end{array}$ \\
\hline Printing & 000101 & $\mathrm{Q}$ & $\begin{array}{l}\text { Multiply the number in arithmetic unit by the number } \\
\text { in memory cell Q, and reserve the result in the } \\
\text { arithmetic unit }\end{array}$ \\
\hline Halt & 000110 & $\mathrm{P}$ & Print the number in memory cell P \\
\hline
\end{tabular}

Analyze the problem: In classroom, the students joined in classroom learning and completed the deep and fine processing of new knowledge under the guidance of the teacher by recalling the pre-class offline self-learning contents.

The polynomial machine language (Figure 7) was written rapidly through group cooperation in class with the machine language mastered before class.

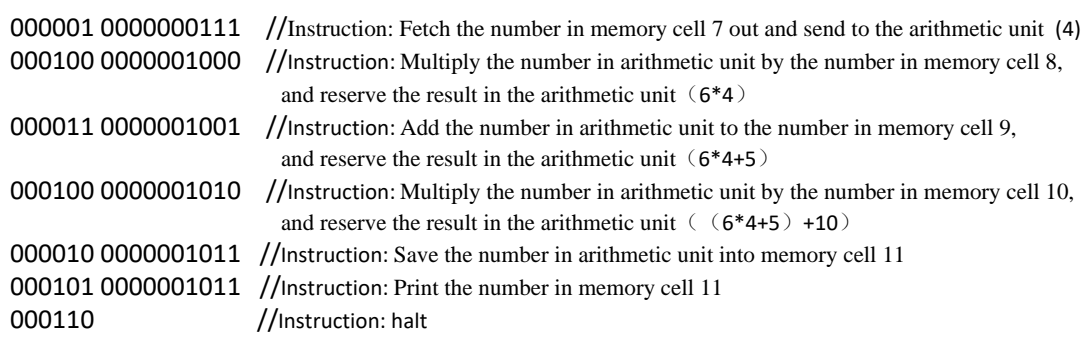

Fig. 7. Polynomial Machine Language 
Continuous explanation of teacher: The fast operation calculation can be realized only by reading and saving the program and data in the computer in advance. The concept of saving was elicited, and the knowledge points, such as conceptual structure of memory, memory matrix, and the logical transformation relation contained, were deeply interpreted. The memory structure representation solving the polynomial was drawn, as shown in Figure 8.

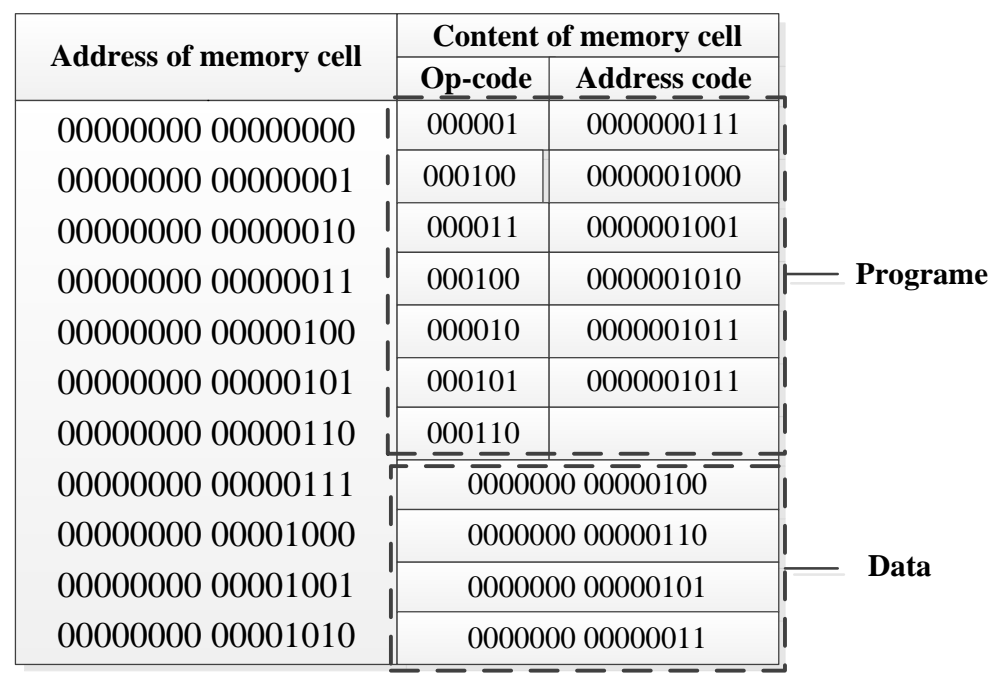

Fig. 8. Schematic of Polynomial Memory Structure

The working mechanisms of controller and clock control were introduced to enable the computer for automatically executing the program. The teacher let the students know that the execution process of an instruction was an orderly transmission of all types of level signals generated by the clock generator to each component under the control of clock cycle, as shown in Figure 9. In this way, understanding the automatic execution of machine-level routine became easy. 


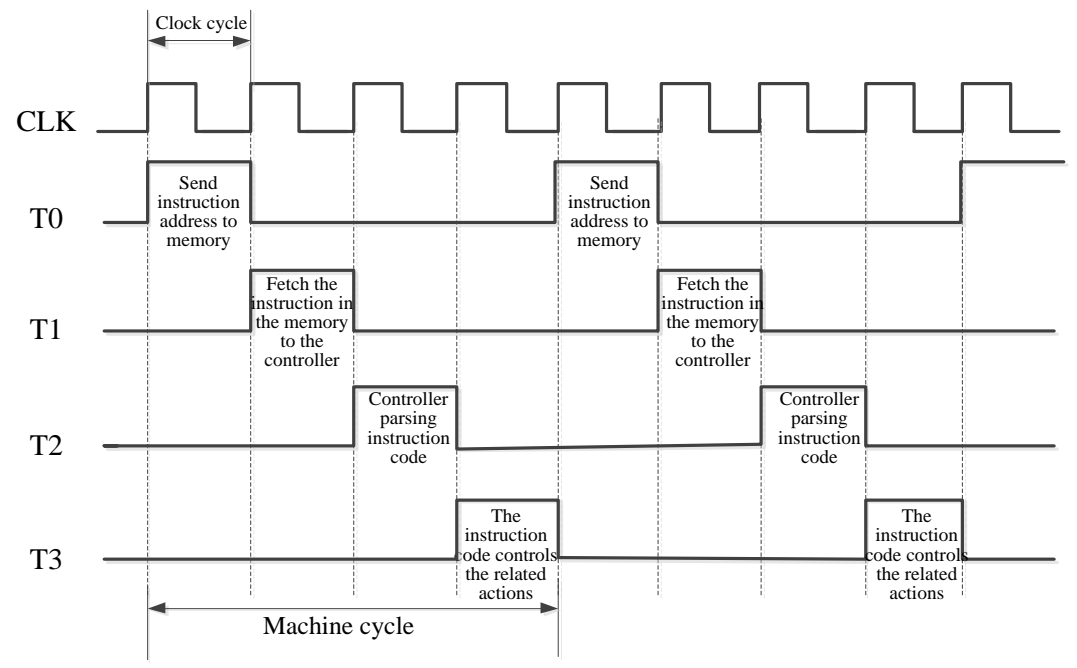

Fig. 9. Clock Cycle Chart

Solve the problem: The students grasped the machine instructions, algorithm compilation, memory structure, and automatic control, and blended the learning contents through the cascade learning of the above knowledge points, thereby completing the study of automatic execution of machine-level routine, as shown in Figure 10. They deepened their understanding of the internal structure of John von Neumann machine via the execution process of machine instructions in arithmetic unit, controller, and storage.

During the whole teaching process, the students were driven to actively participate in the interaction in class by flexibly using group discussion, collaborative learning, interaction, and process evaluation. 


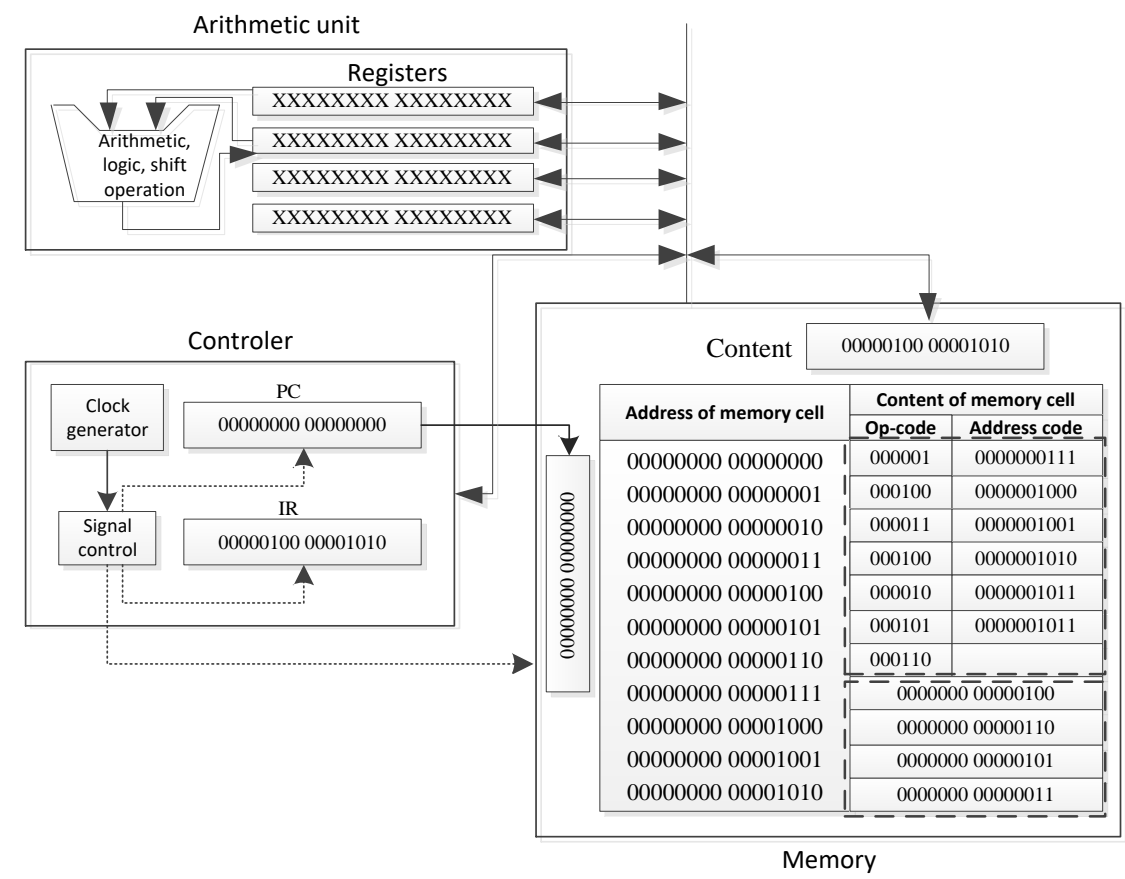

Fig. 10. Execution Process of Machine-Level Routine

Extend the problem: After class, platform testing and resource pushing were introduced to further enrich and extend the learning contents, realize the migration and application of knowledge, cultivate the students' learning interests, and inspire their thinking of knowledge innovation. The following knowledge extension was completed in this case: execution process of assembly program, clock control, logical calculus, address decoder-memory matrix, and execution process of John von Neumann machine.

Evaluate the problem: This module aimed to assess the understanding and application of knowledge. The original data form of the TOPSIS method was obtained in accordance with the hierarchical classification evaluation method and survey on expert scoring, as shown in Table 3. 
Table 3. Hierarchical Classified Evaluation Weights of Machine-Level Routine

\begin{tabular}{|c|c|c|c|c|c|c|}
\hline Module & $\begin{array}{l}\text { Knowledge } \\
\text { point }\end{array}$ & $\begin{array}{c}\text { Learning } \\
\text { layer }\end{array}$ & Evaluation type & Expert 1 & Expert 2 & Expert 3 \\
\hline \multirow{11}{*}{$\begin{array}{l}\text { Execution of } \\
\text { machine level } \\
\text { routine }\end{array}$} & \multirow{5}{*}{$\begin{array}{l}\text { Machine } \\
\text { program, } \\
\text { automatic } \\
\text { control }\end{array}$} & \multirow{5}{*}{$\begin{array}{l}\text { Cognitive } \\
\text { layer }\end{array}$} & $\begin{array}{l}\text { Self-examination of learning } \\
\text { progress }\end{array}$ & 6.0 & 10.0 & 8.0 \\
\hline & & & Platform testing & 10.0 & 9.0 & 10.0 \\
\hline & & & Questioning in classroom & 7.0 & 8.0 & 6.0 \\
\hline & & & After-class assignment & 8.0 & 10.0 & 12.0 \\
\hline & & & \begin{tabular}{|l|} 
Random sampling \\
examination
\end{tabular} & 8.0 & 7.0 & 6.0 \\
\hline & \multirow{6}{*}{$\begin{array}{l}\text { Automatic } \\
\text { execution } \\
\text { process of } \\
\text { calculation }\end{array}$} & \multirow{6}{*}{$\begin{array}{l}\text { Application } \\
\text { layer }\end{array}$} & Peer review & 6.0 & 8.0 & 6.0 \\
\hline & & & Evaluation by group leader & 6.0 & 8.0 & 12.0 \\
\hline & & & Intergroup evaluation & 10.0 & 7.0 & 8.0 \\
\hline & & & Defense in flipped classroom & 14.0 & 9.0 & 10.0 \\
\hline & & & Assignment display & 15.0 & 12.0 & 10.0 \\
\hline & & & Problem extension & 10.0 & 12.0 & 12.0 \\
\hline
\end{tabular}

After the initialization and normalization of the decision matrix, the positive and negative ideal solutions were calculated as $U^{+}=(0.47,0.39,0.39)$ and $U^{-}=$ $(0.19,0.23,0.19)$, respectively. The Euclidean distances $D_{i}^{+}$and $D_{i}^{-}$were calculated, the ratio $C_{i}$ from each evaluation object to the optimal scheme was solved, and the evaluation index were sorted (Table 3).

Table 4. D Table and Sorting

\begin{tabular}{|l|c|c|c|c|}
\hline \multicolumn{1}{|c|}{ Evaluation type } & $\boldsymbol{D}_{\boldsymbol{i}}^{+}$ & $\boldsymbol{D}_{\boldsymbol{i}}^{-}$ & $\boldsymbol{C}_{\boldsymbol{i}}$ & Sorting \\
\hline Self-examination of learning progress & 0.3145 & 0.1221 & 0.2797 & 8 \\
\hline Platform testing & 0.1934 & 0.2857 & 0.5963 & 4 \\
\hline Questioning in classroom & 0.3455 & 0.0424 & 0.1093 & 10 \\
\hline After-class assignment & 0.2280 & 0.2315 & 0.4456 & 5 \\
\hline Random sampling test & 0.3376 & 0.0600 & 0.1509 & 9 \\
\hline Peer review & 0.3678 & 0.0300 & 0.0754 & 11 \\
\hline Evaluation by group leader & 0.3087 & 0.2022 & 0.3958 & 6 \\
\hline Intergroup evaluation & 0.2550 & 0.1476 & 0.3666 & 7 \\
\hline Defense in flipped classroom & 0.1257 & 0.2881 & 0.6962 & 3 \\
\hline Assignment display & 0.0700 & 0.3477 & 0.8324 & 1 \\
\hline Problem extension & 0.1500 & 0.3655 & 0.7090 & 2 \\
\hline
\end{tabular}

The index weights were assessed in accordance with the sorting results, and the learning effect was scientifically evaluated. The teaching reflection was implemented with the problems, and the teacher was aware of the teaching process. Various links, such as course content allocation, teaching case, and flipped classroom, were improved and applied to the next teaching cycle. 


\subsection{Teaching effect}

The proposed hierarchical blended teaching method and traditional blended teaching method were conducted on the college computer course learning among 2020 electronic information engineering major and big data major students. This process was performed to verify the feasibility and effectiveness of the proposed teaching method. After the course was completed, a questionnaire survey was conducted on the students and teachers in the course group in allusion to teaching content organization, explanation effect, learning interest, and integration degree with the specialty and satisfaction. The students' participation in flipped classroom, achievement of online examination, and final examination results were calculated, as shown in Figure 11.

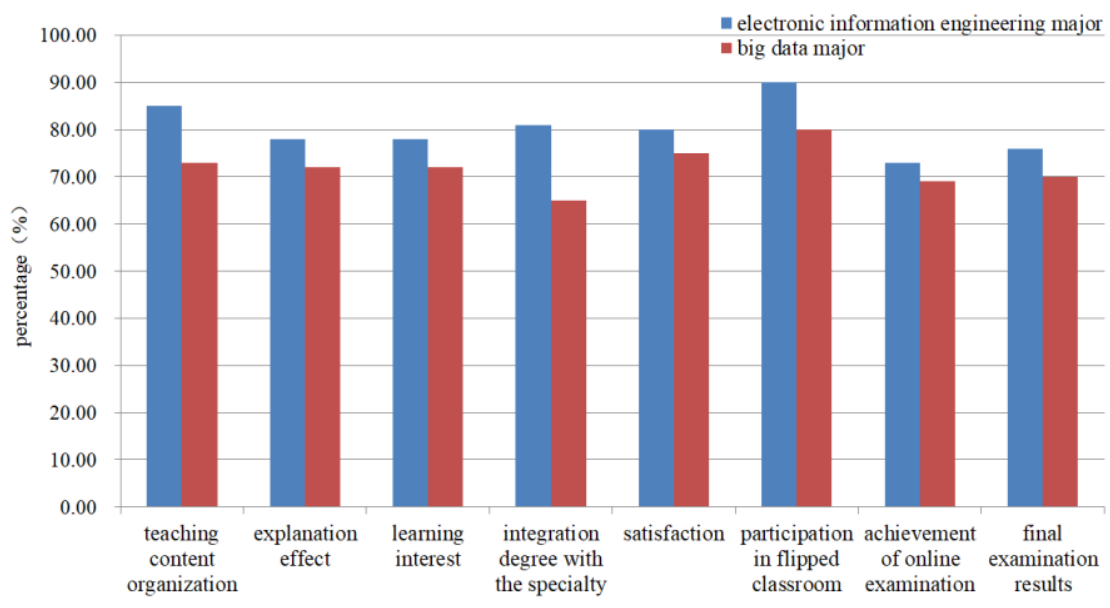

Fig. 11. Teaching Survey and Evaluation Results

The proposed teaching method showed better teaching effect on the electronic information engineering major than the teaching effect of traditional teaching method on the big data major. The students were more interested in the college computer course, and they were relatively active in classroom learning and interacted considerably with the teacher. Their final examination results were superior to those majored in big data, with higher achievement of course objectives, as shown in Figure 12. The professional teaching case was permeated among the students majored in electronic information engineering. The students showed stronger comprehensive ability in solving the problems of the major through computational thinking, and their performance in future work will be satisfying. To sum up, the proposed hierarchical blended teaching method is feasible with favorable teaching effect. 


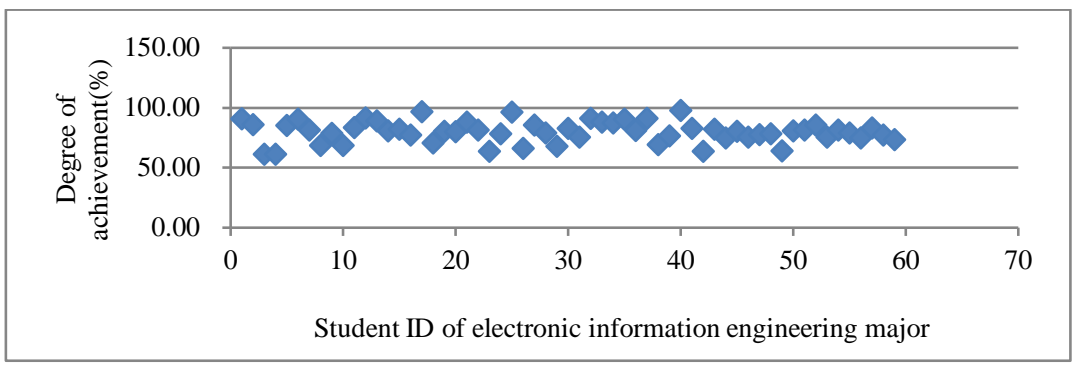

Fig. 12. Scatter Diagram of the Achievement of Course Objectives

\section{Conclusion}

A three-layer (cognitive layer, application layer, and design layer) learning model was established in accordance with computational thinking theory and knowledge cognition process to enhance the deep learning. On the basis of this hierarchical learning model, the course scheme, contents, and resources were rearranged to realize the blended learning, and the learning effect was verified through the hierarchical classification evaluation method. The teaching effect was evaluated through a questionnaire survey on the students and teachers in the course group, and the following conclusions were drawn.

1. On the one hand, the teachers become clear about the course contents and application of teaching method when the hierarchical learning model abiding by the cognitive law of "cognition-application-design" is applied to the blended teaching of college computer course. On the other hand, this condition accords with the students' cognitive logic. The case-based teaching integrating the major, post, and scenario mobilizes the students' learning initiatives and interests effectively, and the experimental results suggest that this model enhances the deep learning.

2. The "5-problem" method (pose the problem, analyse the problem, solve the problem, extend the problem, and evaluate the problem) runs through the whole teaching process. This condition makes the teaching venation distinct, considerably supporting the concept deepening, case extension, and related applications to the majors, and facilitating students' autonomous learning and collaborative group exploration activity.

3. The problem-solving-oriented hierarchical classification method can guide students to utilize the extended resources flexibly, realize autonomous learning whenever possible, and apply what they learn to practice when used to evaluate the learning effect. Great importance is attached to the cultivation of their application ability, which will provide a solid foundation for them to complete IT-related work in the future. 


\section{Acknowledgement}

This work was supported in part by the Vocational Education and Adult Education Division of Jilin Provincial Education Department (2020ZCY279) and the Educational Science Planning Project Research Group of Jilin Province (GH20293).

\section{$7 \quad$ References}

[1] Tartavulea, C. V., Albu, C. N., Albu, N., Dieaconescu, R. I., \& Petre, S. Online teaching practices and the effectiveness of the educational process in the wake of the COVID-19 pandemic, Amfiteatru Economic, 2020,vol. 22(55), pp. 920-936. https://doi.org/10.24818/ ea/2020/55/920

[2] Abdullah, M., Husin, N. A., \& Haider, A. Development of post-pandemic COVID19 higher education resilience framework in Malaysia, Archives of Business Review-2020, Vol. 8(5). https://doi.org/10.14738/abr.85.8321

[3] MacIntyre, P. D., Gregersen, T., \& Mercer, S. Language teachers' coping strategies during the Covid-19 conversion to online teaching: Correlations with stress, wellbeing and negative emotions. 2020, System, 94, 102352. https://doi.org/10.1016/j.system.2020.102 $\underline{352}$

[4] Xinhuanet, Wu Yan, Director of the Department of Higher Education, Ministry of Education: To accelerate the transformation of online teaching from "freshness" to "new normal" (July 2020), retrieved from https://news.bupt.edu.cn/info/1234/23882.htm

[5] Xu, X.F., Li, L., Zhan, D.C., \& Zhang, L. Future engineering education form: Serviceoriented education oriented to sustainable competitiveness, China University Teaching (in Chinese), 2019, vol. 2019(5), pp. 4-9

[6] Zhang, H.M., Tuo, M.F., Xie, P., \&An, L. Application exploration of hybrid teaching in "University computer foundation" course, Computer Engineering \& Science (in Chinese), 2019, vol. 41(S1), pp. 170-173.

[7] Wang, F.Q., Li, Y., \& Han, Q.F. University computer basic course based on the "Three Platforms" smart teaching design, Computer Education (in Chinese), 2020, vol. 2020(06), pp. 105-108.

[8] Fang, X. Research and practice of university computer teaching reform under the background of new engineering courses, University Education (in Chinese), 2019, vol. 2019(06), pp. 88-90.

[9] Uzun, A., \& Senturk, A. Blending makes the difference: Comparison of blended and traditional instruction on students' performance and attitudes in computer literacy, Contemporary Educational Technology, 2010, vol.1(3), pp. 196-207. https://doi.org/10.309 35/cedtech/6027

[10] Asikainen, H. Successful learning and studying in Biosciences: Exploring how students conceptions of learning, approaches to learning, motivation and their experiences of the teaching-learning environment are related to study success. 2014.

[11] Marton, F., \& Saljo, R. On qualitative differences in learning: I-Outcome and process, British Journal of Educational Psychology, 1976, vol. 46(1), pp. 4-11. https://doi.org/10.1111/j.2044-8279.1976.tb02980.x

[12] Biggs, J. B., Kember, D., \& Leung, D. Y. P. The revised two-factor study process questionnaire: R-SPQ-2F, British Journal of Educational Psychology, 2001, vol. 71(1), pp. 133-149. https://doi.org/10.1348/000709901158433 
[13] Entwistle, N. J., \& McCune, V. The conceptual bases of study strategy inventories, Educational Psychology Review, 2004, vol. 16(4), pp. 325-345. https://doi.org/10. 1007/s10648-004-0003-0

[14] Lonka, K., \& Lindblom-Ylanne, S. Epistemologies, conceptions of learning and study practices in medicine and psychology, Higher Education, 1996, vol. 31(1), pp. 5-24. https://doi.org/10.1007/bf00129105

[15] Loyens, S. M. M., Gijbels, D., Coertjens, L., \& Cote, D. Students' approaches to learning in problem-based learning: Taking into account students' behavior in the tutorial groups, self-study time, and different assessment aspects, Studies in Educational Evaluation, 2013, vol. 39(1), pp. 23-32. https://doi.org/10.1016/j.stueduc.2012.10.004

[16] Fengfeng K., \& Kui X., Toward deep learning for adult students in online courses, Internet and Higher Education, 2009, vol. 12(3-4), pp. 136-145. https://doi.org/10.1016/j.iheduc. $\underline{2009.08 .001}$

[17] Trigwell, K., Prosser, M., \& Ginns, P. Phenomenographic pedagogy and a revised approaches to teaching inventory, Higher Education Research \& Development, 2005, vol. 24(4), pp. 349-360. https://doi.org/10.1080/07294360500284730

[18] Slack, F., Beer, M., Armitt, G. \& Green, S. Assessment and learning outcomes: The evaluation of deep learning in an on-line course, Journal of Information Technology Education: Research, 2003, vol. 2(1), pp. 305-317. https://doi.org/10.28945/330

[19] Dolmans, D. H., Loyens, S. M., Marcq, H., \& Gijbels, D. Deep and surface learning in problem-based learning: A review of the literature, Advances in Health Sciences Education, 2016, vol. 21(5), pp.1087-1112. https://doi.org/10.1007/s10459-015-9645-6

[20] Dinsmore, D. L., \& Alexander, P. A. A critical discussion of deep and surface processing: What it means, how it is measured, the role of context, and model specification, Educational Psychology Review, 2012. vol. 24(4), pp.499-567. https://doi.org/10.1007/s10648-012-9198-7

[21] Wing, J. M. Computational thinking, Communications of the ACM, 2006, vol. 49(3), pp. 33-35.

\section{Authors}

Xiangming An is an assistant researcher in the Department of Teaching Affairs, Jilin Institute of Chemical Technology, Jilin, China (an8102@163.com).

Chengliang Qu is a lecturer in the Department of Oil \& Gas Storage and Transportation, Jilin Institute of Chemical Technology, Jilin, China (quchengliang1219@163.com).

Article submitted 2021-01-31. Resubmitted 2021-03-28. Final acceptance 2021-04-01. Final version published as submitted by the authors. 